\title{
ENEMIES BY ACCIDENT, NEUTRAL ON THE REBOUND: DIVERSITY AND CONTINGENCY AT THE BIRTH OF WAR HUMANITARIANISM,
}

\section{2-1864}

\section{Guillermo Sánchez-Martínez}

UPNA, Pamplona

guillermo.sanchez@unavarra.es

Received: 12 October 2013; Accepted: 30 January 2014.

Citation /Cómo citar este artículo: Sánchez-Martínez, Guillermo (2014), "Enemies by accident, neutral on the rebound: diversity and contingency at the birth of war humanitarianism, 1862-1864", Asclepio 66 (1): p028, doi: http://dx.doi.org/10.3989/asclepio.2014.02

ABSTRACT: The historiography of the origin and early years of the movement of societies of the Red Cross and the Red Crescent is, in general, highly pervaded by a narrative whose main architect was Henry Dunant himself. So much so, in fact, that there is no satisfactory explanation as to how the attempt to develop medical a technology ended up involving the implementation of a legal technology, namely, Humanitarian Law. In an attempt to critically revise this narrative, a description is made here of that journey, providing evidence on the way in which a technology, even one as highly regarded as the 1864 Geneva Convention, may arise contingently without being intended, not even imagined, within the circles in which it emerged, through diversity interplaying as a collective action, with no need to resort to any explanatory artifice that might demand that the outcomes should actually be the result of any successful intentional route.

KEY WORDS: International humanitarian law; Red Cross; Collective action; Contingency; Henry Dunant.

ENEMIGOS POR ACCIDENTE, NEUTRALES DE REBOTE: DIVERSIDAD Y CONTINGENCIA EN EL NACIMIENTO DEL HUMANITARISMO DE GUERRA, 1862-1864

RESUMEN: La historiografía sobre el origen y los primeros años del movimiento de sociedades de la Cruz Roja y la Media Luna Roja está, en general, muy contaminado por un relato cuyo principal artífice fue el propio Henry Dunant. Tanto, que no encuentra el modo de dar una explicación satisfactoria a cómo el intento de apuesta por una tecnología sanitaria acaba convertido en la constitución de una tecnología jurídica como es el Derecho Humanitario. Intentando evitar esa contaminación, se ofrece una descripción de ese recorrido dando evidencias de cómo una tecnología, incluso una tan respetada como la Convención de Ginebra de 1864, puede producirse contingentemente sin ser buscada, ni siquiera imaginada en los círculos en los que se produce, por la interacción de la diversidad como acción colectiva, sin tener que acudir al artificio de explicaciones que exigen que los resultados lo sean de recorridos intencionales exitosos.

PALABRAS CLAVE: Derecho internacional humanitario; Cruz Roja; Acción colectiva; Contingencia; Henry Dunant.

Copyright: (c) 2014 CSIC. This is an open-access article distributed under the terms of the Creative Commons Attribution-Non Commercial (by-nc) Spain 3.0 License. 
The origin of the movement of the Societies of the Red Cross and the Red Crescent, as now known to us, can be traced back to the 1890s, when premeditated efforts were made to unify the relief for calamities and accidents, emergency medical care, the rescue of those whose lives were threatened, and civil, medical and emotional assistance for the wounded in battle. Each one of these elements had a different background, with mutual influences. Of them all, the relief for wounded soldiers in the field is the element that provided the name and the iconography that is now used for the sum of all these parts. Its genealogy, which began around 1860 , reveals that it was a highly contingent outcome whose goals, rationale and the articulation of the means and strategies involved were modified and displaced over the course of time.

A review of Europe's press in the 1850s and 1860s reveals that all the analyses of international politics at the time were almost wholly dominated by the unbridled conviction that a major international conflict was imminent, whereby a great pan-European war was about to break out at any moment. Although hostilities on such a colossal scale were not seen until 1914 , in order to understand the nature of the beginnings and transformation of what would ultimately become the societies of the Red Cross and the Red Crescent and their charted courses, one has to start with the generalised experience of this latent state of war and the fears of the ramifications that a conflict of such proportions might entail. The tension-laden atmosphere erupted with the Franco-Prussian war of 1870-1871, which was neither as international nor as catastrophic as feared, being concluded in only a few months following an overwhelming German victory and the fall of the Second French Empire (1852-1870). The war ushered in a period of sham "international peace" in continental Europe, especially as of 1878 , dominated by two other forms of confrontation: on the one hand, social conflicts within the very hearts of the nation-states, as the cause and effect, effect and cause of the development of public administrations designed to provide solutions to the population's needs, and which steadily consolidated the model of social nation-state, and on the other, overseas colonial wars. This was the setting that provided the context for advancements in civil society in pursuit of the national exercise of Europe's Red Cross societies in the decades leading up to the Great War. Yet the threat of a major conflict as yet to materialise and the fear of its consequences provided the seedbed in the 1860s for the kernel of charity on the battlefield.

\section{COULD THERE BE SOME WAY IN PEACETIME OF...?}

The wilful origin of the Red Cross societies is to be found, as we know, in two circumstances. The first, the question posed from Geneva in early November 1862 by Henry Dunant (1828-1910), through the pages of the non-trade publication Un Souvenir de Solférino:

Whether means might not be found to form, during a time of peace and tranquillity, relief societies, whose aim would be to cause care to be given for the wounded in time of war, by means of volunteers, zealous, devoted, and well qualified for such a work? (Dunant, 1862a, p. 102)

And the second, the mobilisation attempt he undertook on a personal basis over the following three months, by individually mailing several hundred copies of his Souvenir, whose cover bore the statement ne se vend pas [not for sale], to acquaintances and strangers alike, to the media dealing in current, literary, medical and military affairs, as well as to the successive contacts he was given over this time. ${ }^{1} \mathrm{His}$ message was that Christian charity, humanity and civilisation urgently required (Dunant, 1862a, p. 113) relieving the suffering and avoiding the fatal outcome that inevitably awaited a huge number of soldiers and combatants wounded on the battlefield due to the delay in receiving care; something that could be remedied if there were relief societies.

The evidence shows that the response to the mailings he sent out to individual recipients was divided equally between silence and expressions of empathy, sometimes not without strong disagreements with his proposal, ${ }^{2}$ and that the mailings to the media and publicists received hardly any public echo, with actual acknowledgements being few and far between; there were some even, like the earliest review of his book in early January, which while omitting any comment on Dunant's proposition took the opportunity to rail against warfare. ${ }^{3}$

The collective civil involvement in relieving the sick and wounded in the field, even on a highly organised basis, was not only nothing new throughout Europe, but also an institutionalised reaction: there are myriad examples, some even involving Henry Dunant himself, ${ }^{4}$ of civil mobilisations for providing measures to complement an army's medical resources in an armed conflict and, furthermore, to attend to the wounded. An objective appraisal of Dunant's proposal reveals that his originality did not therefore lie in the institutionalisation of the relief, but rather in his suggestion that such assistance could be guaranteed if that activity, now institutionalised as a pertinent collective action in response to war, instead of being orchestrated once war had been declared through the introduction of boards and committees that were dissolved once the conflict had ended, was arranged through permanent and legally recognised societies that could be organised and available in advance. ${ }^{5}$ His aim was the institutionalisation of a permanent collective action, but the driving force behind this was a personal excitation of people's individual sense of compassion. 
As far as we know, prior to March 1863 there were only four reactions that specifically linked to a reading of the first edition of the Souvenir implied some kind of active commitment: the acceptance of the task of translating it into Dutch, ${ }^{6}$ two exposés of his ideas, one in a magazine ${ }^{7}$ and the other in a newspaper, ${ }^{8}$ and one call for actual action, which came from Gustave Moynier (1826-1910), who barely two months earlier, at the Third International Charity Congress in London, had defended the draft bylaws for the Association Internationale de Bienfaisance and the creation of an international correspondence network for its ongoing cohesion (CIBL, 1862, vol. 1, pp. 393-397, 411-417).

In December, Moynier, chairman of the Société genevoise d'utilité publique, ${ }^{9}$ called upon his board of directors to propose to the shareholders' meeting, as a new line of business for 1863 , the assumption of a project for introducing those societies. The board rejected the idea, but Moynier returned to the fray again towards the end of January, reducing the proposal to be put before the shareholders to the simple drafting of a report by the Société to be presented in September to the next international charity congress, which was to be held in Berlin, and thereby cause that forum to study whether the relief societies that Dunant proposed were a suitable solution and how they could be set up. The board accepted, adding a proposal whereby the corresponding committee for the drafting of the report should be formed by Moynier, Dunant, General Guillaume-Henri Dufour (1787$1875)$, and the doctors Louis Appia (1818-1898) and Théodore Maunoir (1806-1869): which in time would come to be known as the Committee of the Five. The proposal and the committee's composition were ratified at the meeting held on $7^{\text {th }}$ February.

Meanwhile, barely a month after the printers had delivered the only 400 copies of the Souvenir for which a title page had been commissioned, Dunant made the decision to market it, placing an announcement on $2^{\text {nd }}$ December in the Journal de Genève: "To be published on $6^{\text {th }}$ December, available at leading bookshops; A Memory of Solferino. $2^{\text {nd }}$ edition". Nevertheless, far from being a second edition, this involved a thousand copies of remainders from the initial run, which were presented with a new title-page and an introductory page stating that "The author, in response to numerous requests (...) has had to agree to this reprint...". What is more, he had begun amending his text to correct errors and respond to the suggestions received in answers from the recipients of his books. With all those accumulated changes, two months later, on $19^{\text {th }}$ February, and even though the first/second edition had not sold out, he published a so-called third edition in a smaller format (Dunant, 1863), ${ }^{10}$ in which, without mentioning that he had made changes, and together with numerous stylistic alterations and the addition of several notes, he altered the literal sense of his proposal and parts of the reasoning behind it. The proposition was no longer "to form, during a time of peace and tranquillity, relief societies, whose aim would be to cause care to be given for the wounded in time of war, by means of volunteers, zealous, devoted, and well qualified for such a work" (Dunant, 1862 a \& 1862b, p. 101), but instead "to establish voluntary relief societies whose purpose would to give or to cause to be given, in time of war, care for the wounded" (Dunant, 1863, p. 150, emphasis added). Upholding the initial mention of the fact the publication responded to the huge demand he claimed to have received, he rounded off the book's promotion with an exultant coda at the end of the text:

The call has been heard, and from many countries in Europe numerous tokens of true appreciation of this work, from people in all walks of life (soldiers and civilians) have been sent to the author, who remains more convinced than ever that these Societies can and should be created (Dunant, 1863, p. 176).

As if the appearance on the scene of the Société genevoise and the heartfelt compassion conveyed to him by the correspondents who had suffered with the pathetic scenes described in the Souvenir were revealing a society ready to follow him in the project he was proposing, with these two notes he began a narcissistic narrative that informed a progressively enthusiastic and captivated reception of a work of civilisation, which he nurtured endlessly, sublimating any show of attention, presenting criticisms as expressions of the liveliest interest, and reinterpreting his own initial words, if not even inventing them retroactively, to appear as the conscious forerunner of any triumphal achievement that the project might attain. A manner of proceeding that ultimately became a successful marketing ploy for "the work". ${ }^{11}$

\section{PREPARING TO ATTEND THE CHARITY CONGRESS}

The first meeting of the Committee of the Five, whose agenda was to prepare the report for the fifth charity congress, was held on $17^{\text {th }}$ February, at the same time as the revised edition of the Souvenir de Solférino was appearing in bookshops. However, in contrast to the usual discretion that was the norm for the reports prepared for the congresses, the minutes of this committee were surprisingly well publicised. The opinion on the value and purpose of congresses could not be more opposed between Dunant and all the other members of the committee. Moynier was a believer in the culture of congresses. He knew what they involved, took part in them, and shared their working methods. Dunant thought otherwise about societies and congresses, as he believed they addressed issues of much lesser importance (Dunant, 1862 y y 1862 b, p. $113 ; 1863$, pp. 165-166). Accord- 
ing to his successive proposals, the model in which he trusted to change the world was that of the Good News, involving unions and alliances rather than associations and societies: Unions chrétiennes de jeunes gens, Alliance évangélique, Alliance israélite universelle, Alliance universelle de l'ordre et de la civilisation $^{12}$... Moynier, Dufour, Appia, Maunoir, by contrast, belonged to societies because of their philanthropic, scientific and professional remits. This difference of criterion between Dunant and the others meant that at the end of July, Dunant began to disclose the agreements reached by the Committee, via extremely measured "press releases" in which he revealed what the Committee was going to propose, and reinforced the image of a work in progress, in which the whole world was interested, and which was all due to him, presenting himself in the third person.

In the first of these (Gazette de Lausanne, 28 Jul 1863), which began with the message that ended the revised edition of the Souvenir ("The plea made by Mr. Henri Dunant in his book "A Memory of Solferino" has been heard..."), it was clearly stated that the Committee's purpose was "a desire to see the congress strongly support this idea: $1^{\text {st }}$, to engage public opinion in Europe, and $2^{\text {nd }}$ to call upon governments for their opinion and their support". After having magnified the echo his initiative received, ${ }^{13}$ the following could be read:

The opinion of the author of A Souvenir of Solferino (as well as of the Genevese commission) is, that, in each country, committees should be formed -a sort of framework in permanence- who, during time of peace, shall keep themselves constantly informed of every improvement relating to ambulances, new inventions for the transport of the wounded, and so forth; and who shall also endeavour to propagate, as far as possible, among the populations (whence armies are recruited), sentiments of humanity. (A wounded man prostrate on the ground should be regarded as sacred. This has been forgotten only too often).

In time of war, such committees will direct the persons who shall manifest sufficient good will, and above all, charity, to give their personal aid in the ambulances and hospitals, and who may even he placed, for that purpose, at the disposal of the staff. Committees organized in different countries and in divers localities, although quite independent of each other, will find the means of thoroughly understanding each other and communicating, in case of war. The committees and their delegates ought to be officially recognized and accepted by the respective governments. The corps of volunteer infirmiers are always to be amenable to the military authority, to whose discipline they are to be rigorously subjected whenever they take part in a campaign. These corps should be composed of well qualified assistants, who will keep in the rear of the armies, without giving the slightest trouble, causing the least disturbance, or occasioning any expense. The volunteers are to cost the belligerent armies nothing; they are to be called for whenever wanted, and dismissed when no longer required. These well-organized detachments will have their chief and various grades of successive rank. They will have their own means of transport, their provisions, medicines, and surgical accoutrements of every kind. The directing committees will hold the infirmiers at the disposal of the military chiefs.

General Dufour, moreover, desires that throughout all Europe some conventional sign, generally recognised, should be adopted -such as an uniform, or armlet, or something else of the kind, to designate these volunteers, and enable them to be distinguished everywhere. ${ }^{14}$

The release was also received by, at least, the $\mathrm{Ga}$ zette de Neuchâtel and Charles Dickens's London literary periodical, All the Year Round (22 Aug 1863). It was printed in the Journal des débats in Paris (5 Aug 1863) and L'Economiste belge (15-8-1863), and, as a common "loan" between literary journals, three months later in The Record of News, History and Literature, a confederate periodical published in Richmond, Virginia, in what may have been the project's first mention in print published in the United States (26 Nov 1863). There was, nonetheless, a difference: the texts in French had been stripped of the more flagrant exaggerations contained in the versions published by the Gazette de Lausanne, albeit incorporating others, some of which were especially disquieting, such as the one attributing to his own book the intellectual paternity of both the US Sanitary Commission and the US Christian Commission.

Barely two weeks later, Dunant took another step forward and disseminated a second article, whose first part corrected the misleading information provided on voluntary relief committees in the American Civil War, with the second part explaining that the Committee hoped it would be approved in Berlin. It can be seen that the first, literal part was published on the very same day, $15^{\text {th }}$ August, in the Parisian monthly Le Spectateur militaire, as written by one of its editors, E. P. de Lahitolle, and in the Swiss newspaper, the Gazette de Lausanne, as an unsigned news item on the United States; appearing in full the previous day in the Journal de Genève, being reprinted in the Journal des débats on the $22^{\text {nd }}$. The second part contained the draft resolution already partially numbered, accompanied by a comment on the positive role that, if they existed, could be played by such societies in the American Civil War and "at the service" of the Russian government and the Polish national defence committee.

Immediately after the publication of this "press release", which still presented the Committee's activities as focused on the charity congress in Berlin and ac- 
knowledged that the content of the resolutions whose approval was to be sought was at a very advanced stage of preparation before $15^{\text {th }}$ August, the news was received that the congress was being cancelled. The Committee reacted boldly: the Société genevoise d'utilité publique should go it alone and convene an international conference dedicated solely to this matter, which was a highly unusual step. This change of setting, in addition to the fact there did not appear to be any agreement on the report to be presented in Berlin, ${ }^{15}$ led to the disregarding of this reasoned report and the transformation of the corresponding draft resolutions to be taken as advice stemming from a scientific debate so that, with this vindication, they could be followed by whomsoever wanted-into a concordat project, which would be used, furthermore, as the sole platform for all the debates. ${ }^{16}$

By making this change, they were combining the usages of two different spheres of work, namely, congresses and Swiss politics, and making severely displacing the mandate received from the Société genevoise d'utilité publique in February.

Taking part in a congress entailed, firstly, having a point accepted onto the agenda and, following this approval, the commitment to submit a report and a proposal for improving the subject presented, whereby the report would contain the arguments in favour of the proposal, and the proposition for improvement would provide a real solution to one or more of the real problems associated with it. Accordingly, already as of the moment of presentation of the report, the risk of the debate becoming unfocused was minimised. If the draft resolution contained sections or articles (and Moynier had the prior experience of presenting and defending the bylaws for the Association internationale de bienfaisance in the same forum to which the draft was to have been submitted), these were composed in a manner that meant they could be discussed individually, without interfering with each other. The option chosen by the Committee for its solo call upheld the commitment to this working model.

What is more, the fact that the Committee of the Five should choose to present the Conference as a debate on a concordat project evidences the intent of moving towards a multilateral agreement. The way of presenting it reflected both the terminology and the modus operandi specific to the Swiss political context, where those agreements whose content or jurisdiction required the approval of more than two instances of the same recognised level frequently involved the use of the term concordat. ${ }^{17}$ Nevertheless, how and why did they decide to move from a series of recommendations for action to a proposal for a multilateral agreement? There is no surviving documentary evidence from those days to explain this. ${ }^{18}$
The $26^{\text {th }}$ October was the date set for the start of the Conference, and an announcement was drawn up with a letter of presentation for the Concordat project that was to be the subject of discussion (CIGa, 1863). Nevertheless, for briefing purposes, and instead of a report, inclusion was made of "the three" articles published in the press, one in June, another in July and the third in August. The last two ones were, as noted, precisely the ones written by Dunant. ${ }^{19}$ And the second one, furthermore, instead of being presented as published by the Gazette de Neuchâtel, which was the first publication to do so, was introduced as having appeared in the Journal des débats, which had taken it from the former. The announcement thereby gave the impression of addressing a topic that had been maturing for a long time, which a wide array of publications had frequently echoed and which had been receiving an enthusiastic reception. By including these texts, the announcement also conveyed the message that Dunant was in complete control of affairs, as the concordat project was explained by a long excerpt from Souvenir, followed by a description of the allegedly extraordinary welcome Dunant's idea had received, and completed by the detail of its application in North America and the model proposed for Europe, as the conference call had a strictly European scope.

Yet the Conference needed a name, and the one they chose, "International Conference for examining the means of providing against the Insufficiency of the Sanitary Service amongst Armies in the Field", led to numerous disagreements. Indeed, an argument repeated in the Souvenir de Solférino was the quantitative imbalance between the means available to military medical care and those resources actually required in the event of a major battle, and almost everyone agreed about this objective imbalance, although there were discrepancies over how this divergence could be resolved. Yet describing this imbalance as an "insufficiency of medical services" was interpreted as an accusation of incompetence, especially when it was considered that the concordat's articles stated that civil relief societies would study the organisation of military medical care with a view to improving it. In military circles throughout Europe, many received this combination as an insult and an interference that, in many sectors of the French army, added to the poor reception of the Souvenir, as they understood it ridiculed and embarrassed them. ${ }^{20}$

In other matters, the concordat project contained few changes in content as regards the proposals already made in the press releases: the main differences being that the communication between committees would be undertaken through the Geneva Committee, and that if there were women among the voluntary nurses their duties would be confined to hospitals. 
In order to disseminate the announcement, use was made of the charity correspondence network approved the previous year at the London Congress, ${ }^{21}$ and this meant that it would also be sent to other contacts. For his part, Moynier, who was to have travelled to Berlin to attend the Charity Congress and the International Statistical Congress that was to be held the preceding week, to which he had been appointed as a delegate by the Swiss Federal Council, had to cancel the journey and his delegation in order to oversee the Conference's organisation. ${ }^{22}$ What is more, it was decided that Dunant should travel to Berlin, to the Statistical Congress, and make the most of the trip to visit different Central European cities in order to further publicise the event.

Attending the Statistical Congress in Berlin was expedient because a large number of those likely to have attended the now cancelled Charity Congress would be present in different sections of the event, as it addressed, albeit from another perspective, many of the subjects debated in those congresses, and because it was the largest and politically most important of the international congresses that were beginning to flourish in Europe. Its sessions classified, ordered and related those matters for which improvements were sought, and discussions were held, with the aim being transnational standardisation on what data had to be gathered on which items in order to effectively verify whether the solutions given to problematic issues actually led to their improvement. As each State's commitment to a specific and focused data gathering process added some bias to its political management, the aim was that the recommendations would receive the vote in favour of the delegates from the governments to which they were to be sent, thereby making the congresses a place for the definition of management par excellence. One might well be surprised by this dovetailing of scientific methods and political management that was typical of the ideology of progress, but the shared conviction was that

Although it may well be science, art or method, there is no doubt whatsoever that statistics exist for the good of humanity. What is their purpose? What end is sought by the work of those who have dedicated their efforts to them? To discover under the influence of what laws and what institutions, in what physical and economic conditions man's wellbeing is more complete, and to uncover the sources of evil which halt humanity in his progress. ${ }^{23}$

For their part, ever since they had been promoted by some of those attending the penitentiary congresses prior to the liberal uprisings of 1848 , the charity congresses had invariably maintained as their mission "the physical, intellectual and moral betterment of the working and indigent classes". It was a practical expression of the humanitarian precept that since the end of the 1820s had become consolidated as an inseparable partner to faith in progress and to an understanding of history in which any scientific progress was deemed to be humanitarian, and this applied to any solution involving social enhancement. ${ }^{24}$ Both the political action of governments -including that of absolute monarchies and parliamentary absolutisms-, and liberal philanthropic action, were expressed and undertaken as humanitarian in that sense (albeit within the boundaries of their other interests). An associated circumstance that is readily apparent is that the political actions that became widespread due to the directions taken by the statistical congresses, and the liberal philanthropic actions that were encouraged from sectorial congresses, such as those on charity or for the promotion of social sciences, not only connected with the affairs addressed at the charity gatherings, but on many occasions they were also undertaken by the same people. This meant that any practical intervention (governmental or liberal) designed for purposes of social development at that time pivoted largely around their collective action, which established contingent conventions, and their "humanitarian" activity, which developed them in partial solutions.

In any case, attending the Statistical Congress in Berlin was a logical step because those attending the Fourth Section, whose focus was on "Health and Mortality in the Civil and Military Classes" (Gesundheit und Sterblichkeit der Civil- und Militärbevölkerung), were potentially interested in the specific subject matter of the Conference convened in Geneva. Yet what it had above all, at least for Dunant, was the fact that the French-speaking clerk who was to help the section's coordinator, Rudolf Virchow (1821-1902), in the bilingual conduction of the sessions, was none other than his Dutch translator, Dr. Basting, thereby making it easier to spread the word about the conference call and, perhaps, include the matter in the discussions (which would be difficult as it was not part of the approved programme).

With a view to making the most of his journey, Dunant drew up a list of contacts. ${ }^{25}$ Most of them were agents on the charity correspondence network, regarding whom Moynier had drafted a letter of introduction for him, ${ }^{26}$ or actual friends of Moynier. The rest were almost all contacts provided by the historian and evangelical pastor Merle d'Aubigné (1794-1872) and the clergyman from Neuchâtel, Abraham Pétavel (1790-1870), a tireless champion of a Christian-Jewish alliance.

\section{A SUCCESSFUL DISPLACEMENT}

By now in Berlin, coinciding with the start of the fourth section of the Congress on $9^{\text {th }}$ September, Dun- 
ant was granted permission to distribute copies of the conference call to those in attendance, who were informed that the subject was also dealt with in $\mathrm{Mr}$. Dunant's text "Eine Erinnerung an Solférino, Basle, 1863 ", which was available in the reading room. ${ }^{27} \mathrm{Al}-$ though this "hand-out" was the normal procedure for conveying information on matters not included in the programme, while still related to its purpose, ${ }^{28}$ Dunant must have felt it was not being given the importance it deserved. Deciding to appeal to the highest levels, on the following day he submitted a letter addressed to the chair of the Congress, Ernst Engel (1821-1896), an old acquaintance of Moynier, in which he called for the Congress to issue an official statement supporting and sharing the idea of creating "Permanent international relief societies for soldiers wounded during wars" (CIS, 1865 , vol. 2, pp. 490-491). On Saturday $12^{\text {th }}$, at the plenary session of the Congress, before giving way to the announcement of the fourth section's resolutions and their vote of approval, and following the custom of reading out any expressions of support or any correspondence received, Engel read out Dunant's letter, deciding to pass it on to the fourth section, which was the one concerned with the matter. And, indeed, after the presentation and discussion of the resolutions adopted by that section, Engel handed the floor over to Basting so that he could "report on the conference announced by Mr. Dunant". Without exceeding the forum's mandate, Basting invited those attending to the international congress that "the Geneva Committee" was planning to hold in October in order to study how those societies could be created. Chairman Engel considered that the matter was not one that required a vote, and so all the Congress needed to do was acknowledge that it had been informed, hoping that the Conference would help "to reduce the sacrifices made in terms of health and the lives claimed by battles" (CIS, 1865, vol. 2, p. 500). In other words, the International Statistical Congress in Berlin simply conveyed the information according to standard formal procedure. $^{29}$

Nonetheless, the fact that the annals of history have recorded that the proposal was received with the utmost expressions of enthusiasm, and that the Congress had passed a resolution that was wholly favourable to the project, is once again because that is precisely what Dunant led people to believe, literally saying so in another "press release" that was published in, at least, the Gazette de Lausanne and Nouvelliste Vaudois on the $18^{\text {th }}$, and in the Journal de Genève on the $19^{\text {th }},{ }^{30}$ but, especially, in a circular designed to marshal attendance at the conference that he had printed in Berlin three days later, disseminating it motu proprio as a supplement to the original announcement:

The conclusions of the $4^{\text {th }}$ section have been unanimously adopted with great expressions of approval.
In view of the favourable response his plan received at the Statistical Congress, the Geneva Committee proposes, in addition to the Concordat project..

When, following its approval, the Geneva Convention began to be acclaimed by those involved in the movement in favour of relief societies as a milestone of civilisation, the landmarks in the genealogy from which it was understood to have stemmed were imbued with a halo that gave them retroactive legitimacy. The "Berlin Circular" was raised to the altars because it contained the first defence of neutrality that was expressed in the entire process, and its sacralisation meant its content was indubitable. This is a glaring example of an extraordinarily common phenomenon that cannot be disregarded: overlooking the facts in favour of the memory created around them. In this case, the phenomenon went so far that only four years later, at its next session, held on this occasion in Florence, and convinced by that sacralisation that it had fathered the Convention, the International Statistical Congress itself approved two recommendations to governments reaffirming the resolution adopted (as if it had existed) following the debate (as if it had existed) on relief societies at the Berlin event in 1863 (CIS, 1868, p. 479).

It is well known that in the Circular, and with no consultation whatsoever, Dunant supplemented the Conference's concordat project with three petitions, namely, (1) that governments would host national committees formed by the most dependable and highly respected individuals; (2) that they would proclaim the neutrality of military medical personnel and those reporting to them, including voluntary nursing staff, to ensure they were recognised as such by the belligerent parties; and (3) that in time of war they would allow the access of the means for transporting the people and supplies sent by the relief societies to the theatre of war. What is more, the text of the Circular mentioned matters that had not been addressed beforehand, such as the risk that voluntary relief could be exploited for espionage purposes.

It is obvious that the distribution of the Circular and the tone of its content were influenced by the contacts and conversations from before and after the Statistical Congress, in the receptions held after its closure, involving people for whom on this occasion the news did not reach them within the context of a presumably shared compassion. Among the reactions, Dunant was taken aback by the surprising interest shown by the Prussian military authorities, which was due, as he later wrote to Moynier, that neither the army nor the authorities had heard anything about the project. ${ }^{31}$ Just one year before, Otto von Bismarck (1815-1898) had delivered his famous "blood and iron" speech before the Budget Committee of the Landtag (lower parliamentary house), and Prussia launched an ambi- 
tious plan to become a new hegemonic power, where military preparedness was far from being a minor issue. ${ }^{32}$ Furthermore, as regards relief societies supporting the army in the field, they had the precedent of the role played by the Johanniterorden (Evangelical branch of the Knights Hospitallers of Saint John of Jerusalem), a military order re-formed a few years earlier, providing relief for the army, specifically in the war in Italy in 1859 and $1860 .{ }^{33}$ However, as the only direct documents we have from those three days are the letters Dunant sent to Moynier, and there is no way of knowing which parts of his descriptions are reliable and what has been misrepresented, we cannot say why he added the demand for the neutrality of military medical staff and voluntary nurses to the content of the Circular, or even where the idea came from. ${ }^{34}$

Nevertheless, Dunant was not satisfied with having pre-empted the potential role of governments -because that is precisely what he had done-, as he also sent the Circular, accompanied by copies of the original announcement of the conference, to the ministers responsible for matters of warfare in all European countries, as these recipients had not been considered in the initial correspondence. By inviting them, he raised the universe of those invited to the Conference to a new sphere, driven by reasons other than charity, compassion or philanthropy; involving a new channel, beyond sentiments, namely, jurisdiction. He also sent copies of the Circular to the press: it was published by, at least, the Gazette de Lausanne on the $24^{\text {th }}$ and the Journal des débats on the $26^{\text {th }}$. By that time, the posting from Geneva of the original announcement had already begun to return some results: the French army's official mouthpiece of military information, Le Moniteur de l'armée, echoed it on $21^{\text {st }}$ September, and the radical Deutsche Blätter, in Leipzig, published an article by the republican Guido Weiss, presenting it as a move against war. ${ }^{35}$

The novelty of openly calling upon governments to uphold the neutrality of army medical staff and voluntary nurses, publicly disclosing that the matter was to be addressed at an international conference that had already been called, meant that each government -unaware of whether any others were going to attend- had no choice but to make an appearance, to find out what was going on and avoid becoming sidelined. The engagement of public or professional opinion through the printed media, however, did not increase significantly. It signalled the beginning of the involvement of the military, although, significantly, civilian medical journals continued to be uninterested. It is no doubt significant that throughout this entire process of appealing to the civilian population with greater economic and cultural status, the civilian medical class did not feel involved, even though the matter alluded to the creation of civil relief societies. It is certainly true to say that military and civilian sanitary care followed different paths and, from the perspective of civil medicine, the issue naturally concerned professionals within the military. Furthermore, far from the impression conveyed, one must suppose they were mostly in the dark, as the project had received hardly any coverage in the press: it is extremely difficult to find any articles published on the subject in any European country by publications involving the general press or by military, medical, philanthropic, religious or current affairs journals that commented on the idea, or even mentioned it prior to October, apart from those already specified here. ${ }^{36}$ The calls for involvement in collective tasks that prevailed in the civilian medical press were of a corporate nature: the demand for the free right to practice a profession, the association for defending their class interests and, most specifically, the creation of welfare and friendly societies for them and their families. This lack of reaction must also be explained by the fact there were some who were aware of the issue but deemed it to be of no interest.

\section{THE DELIBERATIONS AT THE GENEVA CONFERENCE}

The success of the twin announcements was, nonetheless, somewhat limited. ${ }^{37}$ Only 36 people gathered in Geneva, with twelve of them being from Switzerland itself, including the five members of the Committee. All-in-all, nine had been sent (without official powers) by their respective war ministries -with seven of them being army doctors-, six were government delegates -all military doctors except one, who although a doctor was not part of the military-, five personal advisers to monarchs or family members involved in their governments, four consuls posted in Switzerland, and seven civilians associated with charity or philanthropy. No one attended from Portugal, Belgium, Norway or Denmark, although their governments sent letters of apology for not attending. Three of those attending (including Moynier) were delegates from the international charity network, and of the other 38 apology letters for not attending, eleven came from participants at the Charity Congress in London and fourteen from other familiar names in the world of charity and philanthropy $(\mathrm{CIGC}$, 1863, pp. 16-30, 100; Dunant, 1864, p. 18).

For such a small forum, nonetheless, it had several virtues. A very diverse geographical provenance, a high proportion of medical professionals with military backgrounds -most of whom had battlefield experience-, a very specific agenda, an open calendar and no allegiance in terms of party, practice, ideology or nationality. They were, of course, conditioned by their own personal pasts, although, according to the Conference proceedings, those who spoke, essentially the army doctors and members of the committee, apparently did so with the utmost freedom. This had the ad- 
vantage that the discussion of the subject proceeded, generally speaking, not as an argument to see who was right, but as a continuous stream of reasoning designed to identify the characteristics to be fulfilled by the relief societies, their performance and operations, with the aim being to overcome those aspects that might pose unacceptable barriers for those who might oppose their existence or might be in a position to block their activities. In other words, they were contributions designed to lay down the terms and conditions that would render them possible, thereby restoring in practice the purpose originally to be pursued at the aborted charity conference in Berlin. Thus, surprisingly, the debate on whether or not it was suitable for permanent relief societies to exist did not materialise. Even those who declared that in their view, and regarding the specific case of their own country, the resources and organisation of army medical relief were sufficient to cater for all adversities, so they did not need them, took part in the discussion suggesting alternatives to help overcome the potential drawbacks. This approach was possible because the delegates from governments and war ministries had not been sent to reach a decision, but instead to observe and report back on the matter upon their return. The majority had not been briefed in any way. This meant that those attending could provide personal opinions without the need to argue in any way to defend any external status quo. The fact that they did indeed make the most of these unfettered circumstances was undoubtedly due to the way the meeting was chaired, as it was brought back into line whenever necessary.

A further positive factor was precisely the diversity of nationalities. The people present were forced to consider the matter from different viewpoints: belonging to the army suffering the casualties, the fact the wounded belong to the enemy they are fighting, and that they are witness to what is happening to the wounded of two armies that are unrelated to them. These differing perspectives were compounded, furthermore, by the fact that none of them could look for support in any aspect of their own country's culture that was not equally valid for the cultures of the other people's countries, so the debate could not be based on any one of those aspects that informed the real or alleged reasons for going to war, or each nation's own specific interests. As the justifications in religions, ethics or politics that might not be of application to the whole lacked purchase, those of a religious nature were raised to the level of common Christianity -charity was Christian, not Catholic, Orthodox, Lutheran or Calvinist- and were on a par with, but neither superior nor inferior to, justifications of an ethical or political nature, which in turn were provided from the level of shared humanitarianism, ignoring the possible resentment or prejudices across nations. For the same reasons, avoidance was made of the possible intellec- tual discrepancies with the numerous and diverse approaches to the succour of the wounded in the form of military carers, Sisters of Charity, Orthodox or Protestant Deaconesses, civilian volunteers, nurses from the Crimean War or the Knights Hospitallers, who were considered exclusively from the perspective of their efficacy for the role they could play on their home soil.

Without going into any great detail about how the conference developed between $26^{\text {th }}$ and $29^{\text {th }}$ October, it may be affirmed that the debate over the concordat project and the subsequent discussion on the petitions contained in the Berlin Circular, modified major aspects of its initial premises. There was no longer any mention of shortcomings in military medical care or that in peacetime the committees would study ways of improving it. Also discarded was the suggestion that voluntary nurses should be subject to military discipline. By contrast, it was agreed that the committees should set up relief facilities as and where requested by the army, that in time of war those committees could ask for assistance from their counterparts in neutral countries, that voluntary nurses would wear a white armband with a red cross for identification, and that the conference's organising committee should become the international promoting committee. And although the speeches repeatedly referred to the obligations regarding the wounded and the need to provide them with the finest and promptest possible care, no mention was made of neutralities, not even as a strategy, until the last day, when after discussing and agreeing upon the terms of the concordat project, doubts were raised over whether to discuss, ignore or ratify the three petitions addressed to governments as contained in the Berlin Circular. At the behest of Basting, and despite Moynier's reluctance, it was agreed to discuss the neutrality requested for army doctors, medical orderlies and army and voluntary nursing staff, as called for in the Circular. What did in fact disappear was none other than the explicit mention of the recognition of the neutral status of voluntary nurses. And yet, surprisingly however, the call for neutrality was extended to cover also ambulances and hospitals, local civilians who may have gone to assist the wounded, "and the wounded themselves", whom it finally included simply for reasons of professional qualms of conscience:

Dr. Landa considers that, given that it involves making a petition, it should be made as comprehensively as possible, and he congratulates the Committee for doing so by joining the wounded among those for whom neutrality is demanded. As a sanitary officer of a permanent army, Dr. Landa, insofar as he is concerned, could never have accepted this exemption of the person of military surgeons from risks, by neutrality, if the wounded were not also allowed the same exemption, for it is their duty to share the same fate as the wounded inder their care. (CIGc, 1863, p. 132, original emphasis). ${ }^{38}$ 


\section{THE CONFERENCE'S LEGACIES AND OMISSIONS}

A study of the debates at the 1863 Conference, and the ensuing disclosure of its results, reveals that the secular reasoning behind its goals and the dissemination of its proposals pivoted around values whose origin had been forgotten. The tacit consensus informed, for example, two maxims that were references to undeniably shared values: war was an affair of States against States in which the individual was an enemy solely by accident, and nations had the obligation in peacetime to do the greatest good to each other, and in wartime to inflict the least harm. Indeed, already by mid 1864, Dunant began to convey the message that the movement of relief societies was the culmination of the fact that love and charity were finally gaining a foothold in the inaccessible bastion of war, introducing the second version of La Charité sur les champs de bataille with a quote by Charles Maurice de Talleyrand (1754-1838), which contained both these maxims, which he took, as many had done so before him, from an 1806 report on the regulation of the seizure of vessels in times of war (Talleyrand, 1806, p. 1462).

Nevertheless, in that report, Talleyrand was simply copying Jean-Étienne-Marie Portalis (1746-1807), a jurist and co-author of the Napoleonic code that still today provides the rationale for mainland Europe's legal system. Portalis, in turn, had formulated it in 1800 in another speech during a parliamentary debate on the reinstatement of the Conseil de prises, the body responsible for deciding upon the validity of the seizure of vessels in times of war, which had been disbanded following the Revolution (Portalis, 1800). Thus, in the years that followed the Geneva Conference, these maxims were attributed to French counter-revolutionary liberals who had declaimed them as an expression of something shared with their audience in order to justify with them the purposes of their discourses. It was not until 1928 that it was clarified that the maxim whereby individuals in war were simply enemies by accident in fact came from the $D u$ contrat social, ou Principes du droit politique (1762), by Jean Jacques Rousseau (17721778). ${ }^{39}$ Neither then nor now has it been noted that the other maxim considered, namely, nations had the obligation in peacetime to do the greatest good to each other, and in wartime to inflict the least mutual harm, is the adage that Baron de Montesquieu (1689-1755) viewed as the natural foundation of the droit des gens (Law of Nations) at the beginning of L'Esprit des Loix (1748). ${ }^{40}$ It is therefore noteworthy that use was being made in 1864 of two maxims of political law expressed in 1748 and 1762, while wholly ignorant of the fact their two exponents were none other than Rousseau and Montesquieu. This comment is pertinent, not to show how culturally submissive they were, but because they help to understand the nature of the world views that informed the mindsets of those involved. The appeal made to them from 1864 onwards was no defence of the ideas of Rousseau or Montesquieu. Indeed, their combination provided a link between two concepts that were, in fact, in opposition: the removal of any arbitrariness in political-social organisation by upholding the legality established by a rational hierarchy of rules based on natural principles, as opposed to a social organisation based on guaranteeing the immunity of each individual's propriety through a social contract. This contradiction reveals that what mattered were not the discourses that rationally explained those values, but rather their operation as compatible values, even though their original discourses were mutually contradictory.

In addition to these concealed roots, the Geneva Conference was also the setting for conscious elimination and wholesale misinformation; the conscious, voluntary elimination of the pacifist options that had already appeared in the Souvenir de Solférino, ${ }^{41}$ and which was specifically undertaken by General Dufour in the Conference's inaugural address, ${ }^{42}$ and wholesale misinformation on significant contributions within the legal and technical-medical contexts that would provide the setting, within a scenario of warfare, for the idea whose possible undertaking was being debated.

Considering that the aim was to contribute from civil society to improving the insufficient resources of military medical care in armies in time of war, and that people in Europe were not only receiving news of the American Civil War, but that different European factions were sending support to their favoured side in that confrontation, it is extremely surprising that none of those in attendance at the 1863 Conference, most of whom were army doctors, did not even mention, with or without reason, the US Sanitary Commission -a private organisation that having lobbied its government for permission to provide relief for the wounded, organised and managed a huge relief network financed entirely through private donations-, nor the observance by the Union army of the so-called Lieber Code -a set of instructions to which it committed unilaterally, asking nothing in return, involving the care and protection of any wounded Confederate soldiers they captured-. It is also quite remarkable that no mention was made in Geneva of the agreements reached during the American Civil War itself to apply neutral status to military doctors, who would be respected and not made prisoners, which had been published in Europe in precisely those terms. ${ }^{43}$

There is a need at this point to stress that neither the idea expressed in the 1862 and 1863 editions of the Souvenir de Solférino, nor the understanding of it that had been gestating in the Committee of 
the Five in the spring and summer of 1863, nor the Conference's goals as stated in its announcement on 1st September, had considered the concept of immunity -neutrality. ${ }^{44}$ When it appeared in the Berlin Circular, it referred solely to "military medical staff and those reporting to them, and including recognised voluntary nurses" (CIGb, 1863, p. 2, original emphasis). Neither the Souvenir nor any of the preparatory documents for the Conference with a confirmed date prior to $26^{\text {th }}$ October, and not even the Berlin Circular, suggests in any way that Dunant or any other member of the Committee of the Five had contemplated immunity for wounded soldiers themselves; but there were, however, discrepancies over the very notion of neutrality. ${ }^{45}$ Even more surprisingly, the Geneva Conference itself did not consider or mention prior calls made in Europe for reforms to the organisation and resources in military medical services for the explicit purpose of redressing the total neglect the wounded ended up facing, such as that made by the Belgian André Uytterhoeven (1799-1868), ${ }^{46}$ or prior and more recent proposals for international treaties on the immunity of the wounded, such as the one being made since 1861 by the Ferdinando Palasciano (1815-1891), ${ }^{47}$ from Capua in Italy, or the one made that same year, also regarding wounded soldiers, although extending it to the ambulances, frontline hospitals and surgeons and nurses attending to them, by the Frenchman Henri Arrault (1799-1887). ${ }^{48}$

Attending to a wounded enemy soldier and not targeting military medical staff in the course of their duties in the field, although not systematic practice were, once again, frequent events, although for Arrault, as in the forgotten reflection by Dr. Henry Dumont, ${ }^{49}$ they needed to be included in Law of Nations:

... It is, I believe, wiser to embody the will of men in a written tract than to trust their generosity, which is as volatile and as capricious as their passions. A sygnallagmatic contract between sovereigns would be stronger and more reassuring than a merely customary practice, and would give the institution I propose a noble sanction, which it would not otherwise have

(Arrault, 1861, p. 31, original emphasis).

The members of the Committee of the Five and those attending the Geneva Conference were not aware of the existence of all these approaches until after it had ended. Regarding the circumstances of the US Sanitary Commission, for example, they did so barely a month later, when its European branch was presented in Europe. Its aim was to collect funds from North Americans resident in Europe and from Europeans who sympathised with its cause in order to finance its operations. Indeed, the immediate approach by Dunant and its notification to other members of the Conference contributed to the rapid spread of its activity through other European countries.
The purpose of these reminders is not to rekindle any sterile debate on "birthrights", but instead draw attention to the unprecedented level of obscurity or ignorance of contemporary matters in a dedicated conference, whose agreements were, nonetheless, more productive that the prior individual requests made. On the one hand, the reality of an international conference, despite attracting only a handful of participants, meant that its resolutions and petitions were an outcome supported by the assurance of arising from a collective cross-border action that involved armies and, therefore, its agreements did not appear to constitute a call for public opinion to take part in the creation of relief societies, but instead as a way of reporting the content of a project under way that now faced a hiatus as it waited for governments to grant their permission and protection. The army doctors sent by governments and war ministries, who had attended as mere observers, on the whole returned home transformed into advocates of the establishment of committees. And on this occasion, the response matched the terms of the call. Only a few committees were set up by private initiative (Italy and Belgium), with the bulk of those being constituted by the authorities, or solely after they had given their permission for this step to be taken. ${ }^{50}$ Thus, in Prussia, where they most explicitly declared their support for the implementation of this idea, it was addressed as an administrative infrastructure of civil support for the army, under the latter's orders and responsibility, with its management and operation befalling the Knights Hospitallers. ${ }^{51}$ In Russia, there was from the start an express desire to impede the access of voluntary nurses to the battlefields. As for Denmark, there was a refusal to guarantee the neutrality of civilians who sought to bring relief to the wounded. ${ }^{52}$ Equally relevant from the perspective of the reactions was that, with the exception of a tiny minority, medical and military professions in Europe remained aloof, not even contributing with suggestions for feasible improvements to the organisation of military medical care or other means that did not involve the highest trusteeship over the creation of those societies. Within the innermost military circles, specifically, strong objections were raised against civilian interference in their affairs, against the possibility that civilians should assess the adequacy of military resources, and even against the neutral status of army doctors and medical orderlies.

Such a trifling response to the creation of relief societies by private individuals comes as no surprise. The peace treaty signed at the Vienna Congress (18141815) had at the time sanctioned the dominance of absolutism throughout Europe, both in terms of the model of the Ancien Régime, and as regards the introduction of the newfangled parliamentary absolutism, 
but absolutism nonetheless, with the only exceptions being Britain's parliamentary monarchy, the Swiss republican system, and from 1830 onwards, the new Belgian state. Europe was bereft of any political systems with absolute freedom of private initiative as in the United States, but instead had systems in which although allowing freedom of private initiative had strong governments that sought to draw a line between public enterprises and private initiatives -the United Kingdom and Belgium-, or regimes with a powerful government in which the freedom of initiative was reduced and the right of association was legally restricted to prior governmental permission that limited civil initiative, as was the case in practically all European countries. These circumstances were all too familiar to everyone. The contract of high politics that Dunant called for in the Souvenir was an agreement among sovereigns to simultaneously and extensively agree to the constitution of societies, something that had nothing to do with an international convention for the granting of whatsoever kind of immunity. ${ }^{53}$ This is what he reaffirmed in his first "press release". Even when from Berlin he launched the petition for the neutral status of military medical care and relief societies -for nurses of the flesh-, what Dunant was seeking was their authorisation. ${ }^{54}$

\section{TOWARDS THE 1864 CONGRESS}

Regarding the political operations of parliamentary absolutism, one of the cogs in the machinery of power between the monarch and parliament was the annual report on the general guidelines of the policy planned for the nation over the coming year. This was the procedure applied in France, among many other countries. In that regard, it so happened that three days after the end of the 1863 Conference in Geneva, Napoleon III delivered his annual speech, the arrêt, to the French chambers in Paris. And when within the framework of international policy he addressed the Russian invasion of Poland, against which voices had been raised in France calling for a military response, the Emperor announced his intention of submitting an immediate proposal for a European congress of sovereigns to rein in military spending, whereby each state would submit its sovereignty to the agreement reached by them all. ${ }^{55}$ Congresses for resolving or alleviating the perpetual state of war had been proposed by numerous sages and collectives, from different standpoints and with different arguments, since the beginning of the $18^{\text {th }}$ century. Yet never had a sovereign or any state proposed one as a higher instance for the management of international relations that would prevail over national sovereignties.

Europe's sundry sovereigns gradually replied over the course of November and December, overshadowed by Great Britain's prompt and unequivocal refusal, as the country's official position since the Crimean War (1853-1856), shared by the majority of its parliamentary spectrum, involved a non-intervention policy precisely as a guarantee of the forthright rejection of any loss of sovereignty of any kind. Spurred on by this first refusal, the German Confederation as a whole also withdrew its support, as did its member states individually upon hearing of this, as no initial provision was made for any changes to the current state of territorial control. The upshot of this was that although there was an overriding belief throughout Europe that the existing warmongering would ultimately trigger a great war that was already deemed to be inevitable, the Emperor's proposal came to nothing.

Within this context of international politics, once the Geneva Conference was over, and in the light of the resolutions approved, and as chairman of the provisional international committee, on $15^{\text {th }}$ November Moynier sent the participants a letter in which, among other matters, he asked them to sound out their respective governments to discover whether these would be prepared to sanction an international agreement in which neutral status would be given in time of war to military hospitals and ambulances, official medical staff, the voluntary medical staff recruited by relief committees, civilians who might come to the aid of the wounded, and the wounded soldiers themselves (CISBM, 1871, pp. 9-10). That letter began the consultation process that would culminate in a multinational treaty, which in fact went even further, signed on $22^{\text {nd }}$ August 1864 as the First Geneva Convention, or "Convention pour l'amélioration du sort des militaires blessés dans les armées en campagne": from the proposal on the foundation of permanent societies for the relief of wounded soldiers in battle, through to a conference to provide against the insufficiency of the sanitary service, to a Convention for the amelioration of the condition of wounded soldiers of armies in the field, with all the differences involved within every one of these sentences.

\section{CONCLUDING REMARKS}

Although the examples presented here date only up until November 1863, the aim has been to show how the fortunes of a proposal for a medical technology (the consolidation of the committees for the relief of the wounded in the field as permanent societies) settled into a legal technology (the Convention approved by the Geneva Congress in August 1864 which, effectively, opened the door on a general basis to the granting of the highest authority required for setting up the committees), which turned out to be the first multilateral agreement limiting the right of sovereignty in favour of the protection of nameless individuals, started the path towards Humanitarian Law. 
In sum, the purpose here has been to show how a technology, even one that is held in the high esteem it deserves, may arise contingently as an unsought outcome, one not even imagined in the circles in which it emerged, through diversity interplaying as a collective action, with no need to resort to any explanatory artifice that might imply the outcome to be the result of any successful intentional course.

In the case of the emergence of the relief societies' movement, one of the factors having contributed the most to its overly hagiographic historiography has been the peculiar personality of Henry Dunant, who gave shape to his Mosaic vocation by setting himself up as the narrator of the journey through a continuous reconstruction of the story. So much so that there is inescapable doubt over when the minutes of the international committee sessions held in 1863 and 1864 were actually written (Pitteloud, 1999, pp. 15-29), whether at the time or through much later recreations of the committee's meetings, to which he could add a date, ornately composed on the basis of his notes.

Indeed, the veracity of the date upon which they were drawn up is questionable for a number of reasons:

- The appearance of the "press releases" and the similarity of the content between those published in July and the middle of August question the absence of meetings between $17^{\text {th }}$ March and $25^{\text {th }}$ August 1863, as deduced from the fact that on the $25^{\text {th }}$ August "the minutes of the last meeting held on $17^{\text {th }}$ March were read and approved".

- It is stretching one's belief to accept that, among the minutes for the four meetings held prior to the Conference, there are proposals made by him involving lists of matters and possibilities that will effectively involve the relief societies a long time later and which no one refers to at any other time or in any other document up until then. A primary example is the organisation of an exhibition of technical-sanitary developments.

- In the minutes of $17^{\text {th }}$ February, Dunant takes the credit for saying that the agreement between high dignitaries "would serve to safeguard any official or non-official person who dedicates himself to the casualties of war". This application was the novelty of September's Berlin Circular.

- The minutes of $17^{\text {th }}$ March note that the Société vaudoise d'utilité publique warmly backs the ob- jective of the Souvenir de Solférino. However, the Société vaudoise d'utilité publique did not do so until the meeting of $30^{\text {th }}$ July, four months later (Gazette de Lausanne, 6 Aug 1863).

- The minutes of $20^{\text {th }}$ October state that Dunant had used the Berlin Circular to call for neutral status also for the wounded, ambulances and hospitals, something that is patently false.

- The end of the minutes of $9^{\text {th }}$ November is a summary of what would in fact occur between the end of December and April, which can hardly have been foreseen at the beginning of November.

- The minutes of $23^{\text {rd }}$ March 1864, attributed to Gustave Moynier, are something of a challenge, because neither the composition nor the handwriting, rounded and upright, coincides with Moynier's style at that time, which in the latter case was tight, sloping and pointed. The signature that is affixed is expansive and straight, being different to the sloping, cropped one that is to be found on a range of documents in his own hand from around those same years that are kept in the ICRC Archive.

By contrast, if we assume that Dunant drafted the minutes at some later date, they neatly fit in with his habit of seeking to situate his ideas and suggestions as preceding the first mention of them made by third parties. This also tallies with the fact that he never showed them to anyone and they appear solely in his eulogy, written by Rudolf Müller 33 years later.

Although these arguments are not sufficiently conclusive to reject the entirety of the descriptions contained in the Minutes, they do present a reasonable amount of doubt as to when they were drafted to reject the attribution of their corresponding date. And if that is not their date, then there would also be some question about the veracity of their content.

\section{ACKNOWLEDGEMENTS}

This contribution is a result of the ongoing research within the framework of the project funded by the Dirección General de Investigación (Spanish Government), "Sanidad militar, medicina de guerra y humanitarismo en la España del siglo XIX" (HAR2011-24134). 


\section{NOTES}

1 A description of the hectic process of mailings and correspondence is to be found in Harouel (2003, pp. 42-47). For this and subsequent deployments, his connections through the Alliance évangélique played a vital role.

2 Especially, the radical disagreement of Florence Nightingale (Gagnebin, 1950, p. 428), which Dunant suppressed for a long time.

3 Antoine Petit-Sen (1792-1870), Le Nouvelliste Vaudois, 5-1-1863.

4 Comité pour les militaires blessés des armées d'Italie. See Boudin (1988, pp. 173-186).

5 This appreciation of the nature of the originality is our own. Dunant's own viewpoint was more messianic, even millenarist, judging by the words attributed to him by Charles van de Velde in August 1863: "My work is to create committees all over the world which can make preparations for the big world-war of which the Prophets are speaking, and which is nearer than one realizes" (Rombach, 1962, pp. 357-358).

6 By the Dutch army doctor Johannes H. C. Basting (1817-1870). The two had met through shared acquaintances in evangelical associationism. The rights over the translation were registered in The Hague on $9^{\text {th }}$ February (Nieuwsblad Voor Den Boekhandel, 19-2-1863). On Basting, see Rombach (1962, pp. 351-361). For the critical reception of the Souvenir in the Netherlands and the commissioning of the translation, see C. J. \& C. K., "Eene Roepstem aan alle Weldenkenden", Militaire spectator, $3^{\mathrm{a}}$ ser, $8(1863,6)$, pp. 370-374, and W. J. Knoop, "Solferino", De gids, 27 (1863, 3), pp. 200-203.

7 Review by the French captain and analyst of military science, Pierre François Le Luyer-Morvan, in Le Spectateur militaire, 152-1863. He reproached Dunant, saying that is he wanted publicists to consider his idea, he had to make sure they could read it. He very politely criticised the overuse of common places, disagreeing with aspects of the proposal such as the fact those societies should concentrate on running the army's hospitals and fixed ambulance bases.

8 A long extract from the Souvenir, published in Journal des débats, 24-2-1863, presented by Saint-Marc Girardin (1801-1873), who attributed the proposal on the creation of societies to a Swiss "longing" for private enterprise and meetings, also noting the contradiction of seeking to promote an idea with a book that was not on sale. Le Moniteur belge reproduced it the next day.

9 Recently appointed chairman of the Société d'utilité publique suisse (Journal de Genève, 25-9-1862), he was, moreover, deputy chair of the board of directors of La Suisse: Institution nationale d'assurances sur la vie and, in May, he was to be the lay candidate to the Consistoire de l'Eglise national protestante de Genève (Journal de Genève, 17-5-1863).

10 Date of the advert in Journal de Genève of the edition in "Charpentier format".

11 The clearest understanding of Dunant's unique personality, which had already been noted in Gumpert (1938), is that provided in Chaponnière (2010), which can be readily supplemented by the documentation provided in Pfersich (2012).

12 Christian Youth Unions, Evangelical Alliance, Universal Jewish Alliance, Universal Alliance of Order and Civilisation.
13 An example: the book was said to have been translated into German, English, Dutch and Italian, and it was being translated into Spanish and Arabic, but it had not been translated into Italian, and all there was in English was an extended excerpt published in Charles Dickens' magazine All the Year Round (16-5-1863), and no Spanish translation saw the light at any time in the $19^{\text {th }}$ century. As far as I know, there was no Arabic version either. The translation into Dutch and the German version had appeared almost simultaneously at the beginning of May, both with the text of an "extended third edition", as prior to May, Dunant had also already modified the "third" edition, adding an eight-page supplement, whose patently propagandistic intent included presenting Florence Nightingale's radical disagreement as warm interest, and the Société genevoise was used as a showcase for those interested in the development of "the work". This was the version read by most of those attending the Conference of Geneva in October 1863.

14 As published in Dickens' journal All the Years Round, 22-8-1863, p. 610.

15 The draft report may well be the text contained in the first part of the Dunant's manuscript BGE-Genève, Ms Français 2099, which reads as follows: "It is in the name of the First International Standing Committee that has been established in the world to study the matter of the voluntary relief to be sent in future to Europe's battlefields, and I have recently expressed to the Congress the wish that this Congress must also use its authority to set up similar Committees throughout the whole of Europe..." (f. 6). Dunant later used this text at different times, starting with the first version of La Charité sur les champs de bataille (Dunant, 1864, pp. 5-6), under whose heading it is now part of a more or less standard anthology, L'Avenir sanglante.

16 Both press releases and the call's concordat project contain literally identical texts, for example, when describing the conduct of relief societies when following an army in the field.

17 For everyone, the "concordat to be agreed among all the cantons (except Obwald, Bàle-Ville, Vaud and Valais, who have chosen not to enter into this concordat), for the recognition of the principle of the free establishment and freedom of practice in favour of doctors and pharmacists" (Feuille fédérale (1862), 3, pp. 267-305).

18 On reaching this point, the objection might be raised that no use is being made of the Minutes of the meetings of the international committee, compiled by Pitteloud (1999, pp. 15-29). This is the preferred option because the accuracy of the date upon which they were drawn up is debatable according to the reasoning presented in the final section of this article.

19 Also the style of the first of the articles, in fact a long extract from the Souvenir, suggests the hand of Dunant. I have no other evidence to prove it with the necessary guarantees.

20 In addition to the known reactions, it should be noted that Souvenir fuelled a bitter controversy in the French army corps over its management, which began in the summer of 1863, with a proliferation of anonymous pamphlets, involving the general in charge of the quartermasters corps in the army in Italy, Roch Pâris de Bollardière (1803-1866), with an expressive La vérité sur le service des ambulances après la bataille de Solférino (Paris, Dumaine, 1864). 
21 ICRC Archive, AF 21-36/1.

22 Le Nouvelliste Vaulois, 13-8-1863 for designation and 25-8-1863 for resignation.

23 Inaugural address at the 1872 International Statistical Congress in Saint Petersburg delivered by Grand Duke Constantin Nikolaievitch of Russia. See Quetelet (1872, pp. 112-115, cit. p. 113).

24 For an approach to the emergence and development of the concept of humanitarianism and its values following the July Revolution of 1830, and its performance as part of a philosophy of history, see the abridged article by Sánchez-Martínez (2013).

25 BGE-Genève, Ms Français 2097

26 ICRC Archive, AF 21-Dossier 3a.

27 The third French edition of Dunant's work was available at the reading room, too ( $\mathrm{CIS}, 1865$, vol. 2 , pp. 241,775$)$

28 This is confirmed by the proceedings that state that at another moment and on a different matter a vote was requested, and the example was given of what had happened with Dunant's request (CIS, 1865, vol. 2, p. 272).

29 This feature had been noted by Gumpert (1938, p. 112), whose report was buried by the hagiographic fervour that subsequently prevailed. It did not resurface until Chaponniere (2010), and, postmortem, Durand (2012, pp. 36-39).

30 In a letter addressed to Moynier on the $13^{\text {th }}$, Dunant said that Basting had sent the release to the Journal des débats -but I cannot confirm it was published-and asked him to send it posthaste to the Journal de Genève, so that others would not publish it sooner, which is, nevertheless, what happened. See Marge... (1954, pp. 424-425)

31 Dunant to Moynier, 13-9-1863.

32 "The great questions of the day were not to be decided by speeches and majorities -this had been the error of 1848 and 1849- but by iron and blood!" (30-9-1862).

33 This was stated by the Prussian members of this order themselves in an article including a lengthy annotated extract from the Souvenir they published on this project, in their Wochenblatt der Johanniter Ordens, 14-10-1863, pp. 253-257.

34 Van Bergen argues plausibly that the proposal was made by Basting (Van Bergen, 2013).

35 "Zum 26. October in Genf", Deutsche Blätter. Beigabe zur Gartenlaube, $2(1863,41)$, pp. 162-163.

36 This may include, together with an article I do not have that appeared towards the end of July in L'Opinion nationale, the lengthy extract from the Souvenir without considering the subject of relief societies published by L'Economiste belge in two consecutive issues in July (nos. 14 and 15, published on the $4^{\text {th }}$ and the $\left.18^{\text {th }}\right)$, and another shorter extract published without any comments, in English, with a different translation to the one published by Dickens, in Bentley's Miscellany (54 (9), pp. 263-269), reprinted on 1-11-1863 in another British publication, The Eclectic Magazine.
37 The conference's progress can be followed in its proceedings (CIGc, 1863), and in its contemporary translations into both Spanish (Landa, 1864) and German (Wagner, 1864). I do not know whether the Resoconto della conferenza internazionale che ebbe luogo nell'ottobre 1863 a Ginevra..., Milan, Guglielmini, 1863, includes a full translation into Italian.

38 On Nicasio Landa (1831-1892), see Arrizabalaga (2013).

39 "War is not, therefore, any relation between man and man, but a relation between state and state, in which individuals are enemies only accidentally" (Rousseau, 1762, cap. 4, "De I'Esclavage", p. 18). It was noticed (inside Red Cross history) by the ICRC 1926-1927 Vice-president, Charles Werner (1928, p. 7).

40 "The Law of nations is naturally founded on this principle, that different nations ought in time of peace to do another all the good they can, and in time of war as little harm as possible, whithout prejudicing their real interests" (Montesquieu, 1748, v. 1, pp.8). This principle was already included as the 4th article in the unsuccessfull Déclaration du droit des gens (Declaration of the Rights of Peoples) that was proposed twice (1793 and 1795) to the Convention by the abbé Henri Grégoire (1750-1831). See Henri Grégoire, Mémoires de Grégoire, ancien évêque de Blois, Paris, Ambroise Dupont, 1837, v. 1, p. 429.

41 "Given that one must renounce the hopes and wishes of the members of the Society of Friends for peace, the dreams of the abbot of Saint Pierre and to the noble inspirations of the Count of Sellon..." (Dunant, 1863, p.150).

42 "Notwithstanding the philanthropic efforts of Peace Congresses -to whose efforts we accord all the respect and sympathy they merit, without being deceived us to the small amount of success which they are likely to attain, as long as human passion exist, and these threaten to continue a long time to come- there will be wars upon this earth; ..." (CIGc, 1863, p. 5).

43 E.g., Gazette medicale de Paris, 27-9-1862, p. 592

44 For its mention as "sauvegarder" [safeguard] in the Committee's minutes of 17-2-1863 (Pitteloud, 1999, p.19), see the final section of this paper.

45 Maunoir to Moynier, 28-9-1863, after reading about the Circular in the press (Durand, 2012, p. 41, n. 13).

46 A reform "that will bring an end once and for all to the cruel, inhumane and desperate suffering of today's sanitary care in most European armies" (Uytterhoeven, 1855, p. 24).

47 A whole series of speeches whose sequence of dates and places can be found in Palasciano (1864).

48 Arrault, like Uytterhoeven, asked "to seek, for a greater promptness in the provision of the relief, a way of curtailing the suffering of the wounded and often a way of saving their lives". He suggested identifying field hospitals with a black flag and distinguishing army doctors with a white scarf, with Palasciano seconding this request (Arrault, 1861, pp. 7, 28; Palasciano, 1864, p. 11).

49 "The issue, under its seemingly naïve appearance, is raised to the heights of a question of Law of Nations. A wounded soldier is no longer a combatant, he will be respected even by the enemy army; is he not entitled, as the foremost reward for his services, to be protected without delay, against any further 
chances of destruction? As from the moment a soldier is put out of action he should not be exposed to the circumstances of a combatant, he is no longer a threat, and should not therefore be himself threatened" (Dumont, 1862, pp. V-VI). The Journal de la Librairie, 7-3-1862, ref. 2001, reported the appearance of Dumont's book, which was announced in May in Le Moniteur Scientifique, 5 (153), p. 360 and, in June, in the covers of the Spanish Monitor de la salud y de la salubridad de los pueblos.

50 A little known, albeit eloquent, example of this dependency is the process of constituting the Spanish committee (GarcíaReyes, 2012, pp. 71-73).

51 For a brilliant exposition in a language other than German, see Hutchinson (1996).

52 See the overview of the situation in different European countries that the Committee drafted in June 1864 (CISBM, 1864, pp. 22-29).

\section{BIBLIOGRAPHY}

Arrault, Henri (1861), Notice sur le perfectionnement du matériel des ambulances volantes, Abbeville, Imp. de Rousse.

Arrizabalaga, Jon (2013, con Guillermo Sánchez-Martínez), “Nicasio Landa, 1830-1891, le Comité de Genève et la première Croix-Rouge espagnole". In Humanitaire \& Médecine. 1. Les premiers pas de la Croix-Rouge, 1854-1870, Genève, Genève Humanitaire, pp. 168-196.

Boudin, H. R. (1988), "La participation de deux Belges étudiants en théologie protestante à la première équipe internationale de secours aux blessés militaires lors de la campagne d'Italie en 1859". In Analecta facultatis theologiæ Bruxellensis: II, 1976-1985, Protestantisme et Université, Bruxelles, Société d'histoire du protestantisme belge.

Chaponnière, Corinne (2010), Henry Dunant: La croix d'un homme, Paris, Perrin.

CIBL (1862), Congrès international de bienfaisance de Londres. Session de 1862, London, Bureau de l'Association Nationale pour le Progrès des Sciences Sociales, 2 v.

CIGa (1863), Conférence internationale pour examiner les moyens de pourvoir a l'insuffisance du service sanitaire dans les armées en campagne, Genève, Imp. Ramboz et Schuchardt.

CIGb (1863), Conférence Internationale, a Genève, le 26 de Octobre 1863. Sociétés de secours internationales et permanentes pour les militaires blessés en temps de guerre, Berlin, Impimerie Royale.

$\mathrm{CIGc}$ (1863), Compte rendu de la Conférence Internationale réunie à Genève les 26, 27, 28 et 29 octobre 1863 pour étudier les moyens de pourvoir a l'insuffisance du service sanitaire dans
53 "If an Austrian general and a French general could have met, in the aftermath of Solferino, sitting next to each other, at the King of Prussia's dining table and engaged in friendly conversation, who would have prevented them from examining and discussing a matter so worthy of their interest and of their attention? In such extraordinary circumstances, such as those that, for example, convene in Cologne or Châlons, the princes of the art of warfare, of different nationalities, could it not be hoped that they would make the most of this kind of congress to formulate some or other international principle, of a binding and sacred nature, which once agreed and ratified would serve as the foundations for Societies of relieffor the wounded in the different countries of Europe?" (Dunant, 1863, p. 165).

54 "That each Government in Europe should deign to extend Its Special Protection and Its Highest Patronage to the national central committee that were to be created in each one of Europe's capitals..." (CIGb, p.1).

55 He had already sent it the previous day.

les armées en campagne, Genève, Jules-Guillaume Fick. [Actual translations into Spanish, see Landa (1864), and into German, see Wagner (1864)].

CIS (1865), Die Fünfte Sitzungsperiode des Internationalen Statistischen Congresses in Berlin vom. 4. bis 12. September 1863, Berlin, R. V. Decker.

CIS (1868), Compte-rendu des travaux de la Vle session du Congrès international de statistique réuni à Florence, Florence, Imprimerie de $\mathrm{G}$ Barbèra.

CISBM [Comité international de secours aux militaires blessés] (1864), Secours aux blessés. Communication du Comité International faisant suite au compte rendu de la Conférence internationale de Genève, Genève, Imp. de Jules-Guillaume Fick.

CISBM (1871), Comité International de Secours aux Militaires Blessés. Actes, Genève, Soullier \& Wirth.

Dumont, Henry (1862), Memoire sur les premiers secours aux blessés sur les champs de bataille, Coulommiers, Imp. de A. Moussin.

Dunant, J. Henry (1862a), Un souvenir de Solférino, Genève, JulesGuillaume Fick.

Dunant, J. Henry (1862b), Un souvenir de Solférino, Genève, JulesGuillaume Fick.

Dunant, J. Henry (1863), Un souvenir de Solférino, Genève, JulesGuillaume Fick.

Dunant, J. Henry (1864), La charité sur les champs de bataille, suites du Souvenir de Solférino et résultats de la Conférence 
internationale de Genève. Neutralisation des ambulances entre armées belligérantes. Sociétés internationales des hospitaliers militaires, Genève, [s.n.].

Dunant, J. Henry (1865), La charité sur les Champs de bataille. Le Traite de Genève et Un Souvenir de Solferino. Associations permanentes et universelles de secours aux militaires blessés, Paris, Hachette.

Durand, André (2012), "Gustave Moynier, du Congrès de statistique à la Conférence constitutive septembre - octobre 1863", Cahiers Geneve Humanitaire, 3, pp. 35-43.

Gagnebin, Bernard (1950), “Comment l'Europe accueillit le Souvenir de Solférino", International Review of the Red Cross, 32 (378), pp. 419-429.

García-Reyes, J. Carlos (2012), with Guillermo Sánchez-Martínez \& Jon Arrizabalga) “Movilización patriótica, medicina de guerra y humanitarismo: la Cruz Roja española en los conflictos civiles del Sexenio Democrático", Estudos do Século XX (Coimbra), 12, pp. 69-86.

Gumpert, Martin (1938), Dunant, the History of the Red Cross, New York, Oxford University Press.

Harouel, Véronique (2003), Genève-Paris 1863-1918: Le droit humanitaire en construction, Genève, Société Henry Dunant, Comité international de la Croix-Rouge, Croix-Rouge française. [PhD Dissertation, Université de Poitiers, 1996].

Hutchinson, John F. (1996), Champions of Charity: War and the rise of the Red Cross, Boulder (Co), West View Press.

Landa, Nicasio (1864), "La Conferencia internacional de Ginebra. Actas de la Conferencia internacional de Ginebra", Revista de sanidad militar española y extranjera 1 (1 to 23), pp. 47-51, 70-74, 91-94, 116-121, 223-228, 377-381, 408-414, 440-447, 519-52, 539-544 y 560-570. [Also, El Mundo militar: Panorama universal, from 15-5-1864 to 22-1-1865].

Marge... (1954), "En marge du Congrès de statistique (Berlin, septembre 1863): Lettres de J. Henry Dunant à Gustave Moynier", International Review of the Red Cross, 36 (425), pp. 424-428.

Montesquieu, Charles Louis de Secondat, baron de (1748), L'Esprit des Loix, [1a ed.], Geneve, Barillot \& Fills, 1748, 2v.

Müller, Rudolf (1897), Entstehungsgeschichte des Roten Kreuzes und der Genfer Konvention, mit Unterstützung ihres Begründers... Stuttgart, Greiner \& Pfeiffer.

Palasciano, Ferdinando (1864), De la Neutralisation des blessés en temps de guerre et de ses conséquences thérapeutiques, Lyon, Imp. d'Aimé Vingtrinier.
Pfersich, Charles (ed.) (2012), Dunant-Moynier, un Prix Nobel peut en gâcher un autre, Lenzburg, Verlag Merker im Effingerhof.

Pitteloud, Jean-François (ed.) (1999), Procès-verbaux des séances du Comité international de la Croix-Rouge, 17 février 1863 - 28 août 1914, Geneva, ICRC and Henry Dunant Society.

Portalis, Jean-Étienne-Marie (1800), [«Discours de Jean-ÉtienneMarie Portalis»]. In "Procès-verbal d'installation du conseil des prises 14 floreal an VIII", in e.g., J. B. Sirey, Recueil général des lois et arrêts, Paris, 1800,1 , part 2, cols. 160-161.

Quetelet, Adolphe (1872), Congrès international de statistique. Sessions de Bruxelles (1853), Paris (1855), Vienne (1857), Londres (1860), Berlin (1863) Florence (1867), La Haye (1869) et St. Petersbourg (1872), Bruxelles, F. Hayez.

Rombach, J. H. (1962), "Two great figures in Red Cross History", International Review of the Red Cross, 2 (16), pp. 351-361.

Rousseau, Jean Jacques (1762), Du contrat social, ou Principes du droit politique, [1aㅡ ed.], Amsterdam, Marc-Michel Rey.

Sánchez-Martínez, Guillermo (2013, with Jon Arrizabalaga), "Si no son conceptos, ¿qué son? El caso del humanitarismo". In The 16th International Conference on the History of Concepts. Proceedings, Bilbao, The Conference, pp. 235-240. [online] available at www.iberconceptos.net/wp-content/uploads/2013/01/ PROCEEDINGSHCGBILBA02013.pdf

Talleyrand, Jean Maurice de (1806), “Rapport a l'Empereur du 20 novembre 1806 a la veille de la publication du decret de Berlin du 21 novembre 1806 instituant le blocus des lles Britanniques", Moniteur Universel (339), p. 1462.

Uytterhoeven, André (1855), Encore un mot sur les moyens de porter immédiatement secours aux blessés sur les champs de bataille, Bruxelles, J.B. Tircher.

Van Bergen, Leo (2013), "Johan Hendrik Christiaan Basting. His Ideas on War and Medicine". In Humanitaire \& Médecine. 1. Les premiers pas de la Croix-Rouge, 1854-1870, Genève, Genève Humanitaire, pp. 55-61.

Wagner, E. R. (comp.) (1864), Die Barmherzigkeit auf dem Schlachtfelde: Eine Erinnerung an Solferino nach der vierten französischen Ausgabe, von Henri Dunant; mit Ermächtigung des Verfassers neu überfest und mit einem Bericht über den Genfer internationalen Sanitätscongress vermehrt von ... Stuttgart, Belser, [CIGc translation, pp. 105-158].

Werner, Charles (1928), "Les prisonniers de guerre", Académie de Droit International. Recueil des Cours, 21, pp. 5-11. 